DANDELION

VOLUME 6 NUMBER I AUTUMN 2015
Dr MARK Wilsher is an artist and associate lecturer in fine art at Norwich University of the Arts. He has exhibited his own artwork at national institutions including the Henry Moore Institute and the ICA. He has published many articles of art theory and criticism in Art Monthly magazine on sculpture, conceptual and socially-engaged art practice.

m.wilsher@nua.ac.uk

Article

\title{
Contemporary Art in the News
}

\author{
Dr Mark Wilsher
}

THERE HAS BEEN AN UNPRECEDENTED SURGE IN THE POPULARITY OF contemporary art in the UK in the last twenty years, linked with Millennial capital projects such as Tate Modern (2000), the initiation of the Frieze Art Fair (2003) and the annual televising of the Turner Prize (sponsored by Channel 4 from 1991-2004). It might be assumed that this has been reflected in an increase in the volume and quality of press coverage, yet a suspicious attitude to contemporary art still dominates the mainstream media narrative. The British Council has noted that,

\footnotetext{
The treatment of contemporary art and young artists in the UK media has been, at best, ambivalent. [...] Mockery pervades, and is seen with the - almost always negative - reception that the Turner Prize is afforded every year.'
}

The paradigmatic instance of contemporary art in the mainstream news media in the UK remains the infamous "Tate bricks" scandal of 1976, reflecting the belief that modern art is essentially a confidence trick or a joke at the expense of the audience. ${ }^{2}$ In this narrative, modern art is a hoax and artworks themselves worthless junk often literally indistinguishable from everyday rubbish.

But it is not simply that the media are against art - in some senses contemporary art has never been more popular or more widely covered in the press. The relationship is more complex, and in fact reflects the way that the discourses of mainstream media and the contemporary art world see the same phenomena in divergent ways. What seem like conservative responses are not 
just kneejerk reactions to an incomprehensible Other, as might be assumed. The way newspapers report on contemporary art is closely modelled on significant tropes and themes within art practice, albeit in a distorted manner.

There has been no systematic analysis of the reporting of contemporary art in the mainstream news media. This is an important topic for artists, galleries and the sector generally, not only to understand how specialist discourse is disseminated into the mainstream, but also in order to affect media strategies for public and commercial institutions. The cultural idea of 'an artist' can be seen reflected in the kinds of stories that regularly appear in the mainstream news media. If, as is often stated, media discourse is influential in the construction of public attitudes, then the kind of messages about the nature of art and artists that are being promoted are evidently of great significance. It is not that the public has their opinion formed directly by what it views and reads, but rather that the media is 'key to the setting of agendas and focusing public interest on particular subjects, which operates to limit the range of arguments and perspectives that inform public debate. ${ }^{4}$

This paper describes a small pilot study into British newspaper representations of contemporary art that I carried out in the summer of 2011. It is based on the proposition that the way the mainstream popular media covers contemporary art has changed radically since the early 1990s, both reflecting and constructing new popular audience attitudes towards avant-garde art and artists. The pilot study set out to test methods, and set benchmarks against which later research might be compared.

Since 2005, the national DCMS/ACE Taking Part survey has collected annual data on audience participation for different art forms, but this is limited to basic data about frequency of engagement and does not include anything on audience attitudes. What is certain is that the audience for contemporary art has grown vastly in the period since the year 2000, as a result of capital projects including Tate Modern (close to 5 million visitors annually compared with Tate Britain's 1.5 million) in London, BALTIC in Gateshead and Turner Contemporary in Margate. ${ }^{5}$

The most significant study of the way that contemporary art is covered by the mainstream media is Peter Hayward's book Picture This commissioned by the Arts Council in 1999. This study focused on the representation of static visual art in the highly fluid and mobile media of film and television. Hayward identified two main paradigms when it came to representing visual art: the artist as tortured genius, and the idea of modern art as 'essentially a con foisted on the art establishment by a coalition of pretentious foreigners and devious entrepreneurs'. ${ }^{6}$ The essays in the book critique various well-known arts programmes including Kenneth Clark's Civilization, originally broadcast in 1969, and John Berger's Ways of Seeing from 1972, but do not engage in a close reading of wider media attitudes to contemporary art. They analyse the techniques with which art is depicted in broadcast media, rather than looking at what is actually being said.

The research reported below is the first dedicated study to provide quantitative data on art-related newspaper stories. The main thrust of the project, however, is qualitative analysis of the stories, based on close readings of the published texts. The analysis is built on a critical interpretation of narrative paradigms, with media stories categorised into the most frequently occurring themes.

There are some obvious representational paradigms that tend to dominate in film and television portrayals of artists that echo everyday clichés about creativity and modern art. As mentioned above, Hayward picks out the 
'tortured genius' and the 'con man,' and Janet Wolff had much earlier concentrated on the stereotype of the artist as an 'asocial being, blessed with genius, waiting for divine inspiration and exempt from all normal rules of social intercourse'. ${ }^{7}$ I was interested to see if these narratives were still prevalent in the twenty-first century, and whether they had been joined by any others.

The study discussed here was undertaken as preparatory work for a wider research project that will compare contemporary media stories with those from the early 1990s and earlier. I decided to look at national newspapers, as these offered sources of non-specialist general interest news stories that would be encountered by readers not specifically looking for artrelated material: Sunday newspapers with their larger arts coverage were excluded for this reason. Printed newspapers also had the advantage of being easily compared with the same sample group from twenty-five years previously, before the rise of online media outlets. This obviously meant excluding a large amount of digital media, online comment and discussion, but such a wide ranging investigation was simply beyond the resources available at the time.

For a period of one month in May 2011 every copy of five national dailies was collected: the Sun, Daily Mail, Daily Mirror, The Times and the Guardian. The sample was selected in order to represent mainstream journalism, both broadsheet and tabloid, from different political positions. Total circulation reached on a single day by all 5 papers is 7,252,000, which is $11.6 \%$ of the UK population according to the Office for National Statistics. Over 26 days there were a total of 130 newspapers studied and analysed.

The papers were analysed for stories involving contemporary art, which was defined as anything intentionally produced as artwork, by artists who were still alive. Therefore most twentieth century Modern art was excluded, as were obituaries (Leonora Carrington died during the study). A few pieces on Barbara Hepworth, relating to the opening of the Wakefield Hepworth gallery were included as exceptions to this rule, since the gallery is intended to show contemporary works. Where possible, web research was used to determine whether an artifact was intended as contemporary art or should rather be understood as design, fashion, or a hobby. In most cases it was possible to track down the maker's website and determine the context they were operating within based on their education, profession and any public statements they may have made. Documentary photography was excluded unless presented within a fine art context (i.e. with a conceptual apparatus that played an important role in the reading of the work). Only significant stories, letters and diary items were logged. Listings, TV listings, and brief previews within defined art sections (e.g. the Guardian Guide) were excluded. Exhibition reviews were included wherever they appeared. One guiding principle was that the stories should be new copy written specifically for the newspaper, rather than edited press releases or agency copy. This ensured that the items studied truly reflected a non-specialist discourse. I intend to analyse the way that specific language migrates from the art world, via press releases and gallery texts, to the media and on into the wider culture as part of a wider project in future.

A total of one hundred and fifteen relevant stories were identified and analysed according to their main theme, and sometimes a secondary theme, with fifteen types of narrative occurring three times or more. These were what we might call paradigmatic narratives around art and artists.

Based on this qualitative analysis of the texts it is apparent that the most frequently asserted attitudes around art are no longer straightforwardly negative. In fact, they parallel very closely some of the key beliefs and characteristics of the art world. Each story can be shown to reflect standard art- 
insider discourse, albeit refracted through the interests and values of the mainstream press.

Breakdown of themes \& number of occurrences

\begin{tabular}{|c|c|}
\hline 22 & Tracey Emin. \\
\hline 21 & Ai Weiwei. \\
\hline 12 & Unusual images. \\
\hline 11 & Unusual materials. \\
\hline 8 & Banksy. \\
\hline 5 & $\begin{array}{l}\text { The Turner Prize. } \\
\text { Sculpture. }\end{array}$ \\
\hline 4 & $\begin{array}{l}\text { Freedom of speech. } \\
\text { Regeneration. } \\
\text { Barbara Hepworth. }\end{array}$ \\
\hline 3 & $\begin{array}{l}\text { The financial value of art. } \\
\text { Art's cynicism. } \\
\text { Controversy. } \\
\text { Rediscovery of lost works. } \\
\text { Street life. }\end{array}$ \\
\hline 2 & $\begin{array}{l}\text { Amazing engineering, Art business, Arts funding, } \\
\text { Art therapy, Celebrity, Collecting, Damien Hirst, } \\
\text { Emotional truth of art, Feminism, Interiors, } \\
\text { Memorial work, Portraiture, Power of the } \\
\text { signature, Vandalism of art. }\end{array}$ \\
\hline 1 & $\begin{array}{l}\text { Arabic arts festival, Architecture, Artistic value, } \\
\text { Artists as unusual people, Art requires humanity, } \\
\text { Art's power to comment, Art's power to shock, } \\
\text { Avant-gardism, Graffiti, Healing power of art, } \\
\text { Human interest, Importance of art, Installation, } \\
\text { Kutlug Ataman, Laurie Anderson, Literature as } \\
\text { art, Logistical problems, Making art approachable, } \\
\text { Michael Craig Martin, New exhibition, } \\
\text { Overlooked everyday, Political art, } \\
\text { Pretentiousness of art world, Public sculpture, } \\
\text { Sarah Lucas, Scandal, Skill of painter, Sociology of } \\
\text { art gallery, Tate, Venice biennale, YBAs, Yoko } \\
\text { Ono. }\end{array}$ \\
\hline
\end{tabular}

Looking at the most popular subject matter for news stories then, at the top of the list, it is immediately evident that strong personalities or celebrity artists feature most often, with Tracey Emin and Ai Weiwei each featuring almost twice as often as the next most frequent category of story. Emin had a large retrospective opening in London during the period of this study, and Weiwei had recently been imprisoned by the Chinese authorities. It is notable that the well-known street artist Banksy also appears high on the list. Basing a news story on the activities or circumstances of an easily recognised figure means that the readership is immediately drawn in, and does not need to be convinced of the interest value of the news event itself. The content or meaning of the art itself seemingly does not need to be discussed when the character of the artist is more important to the story, indeed Donald Kuspit has noted that 'the world 
has come to accept and celebrate the avant-garde artist as a charismatic figure who stands for no particular principles beyond the general principle of creativity. ${ }^{8}$ As with the wider fascination with celebrity in Britain currently, the activities of artists with high name recognition are regularly reported on, and their exhibitions covered in a variety of styles of article: interviews, reviews, comment, and news items.

It would be interesting to study more closely the mechanisms by which an artist is transformed into the media construction of a 'celebrity' artist. In a sense this is just an update of the historic stereotype of the artist as an unusual figure, transgressing the rules of social behaviour with Emin, and the oppressive laws of the state with Weiwei. And yet not all artists are granted celebrity status. One might reasonably add Grayson Perry, Damien Hirst, David Hockney, Yoko Ono, Cornelia Parker, and Anish Kapoor to the list in the British media, but that would be about it.

After this the next most frequent types of narrative are that of the unusual image, subject matter or material. These are often delivered with large spectacular images of the artwork. A typical example would be 'Work of Parts' from the $\operatorname{Sun}^{9}$, which features an almost full-page image from Canadian artist Todd McLellan's Disassembly Series, the component parts of a camera carefully taken apart and arranged. The brief explanatory text is actually smaller than the headline, and just a fraction of the size of the image itself. In the Daily Mirror from 17 May 2011 the image alone is the story. Under the headline 'An Art Attack Victim' the full colour image of a tromp-l'oeil lion leaping from a wardrobe to attack a posed viewer is reproduced. ${ }^{10}$ We are told that this is in Jilin, North East China, but the name of the artist or exhibition is not even mentioned. This is an artwork given to us completely free of any context. The image is the story.

It is easy to understand the popularity and usefulness of these kinds of stories. Artists become suppliers of unusual, often dramatic content for the media. They receive publicity in return although it is rare that much information or detail on the artwork is supplied. As a result the media tends to flatten out existing hierarchies and an internationally lauded artist will be given the same treatment as someone making a portrait of Barack Obama out of Rubik's Cubes (Irish artist John Quigley), ${ }^{11}$ or Seurat's Bathers at Asnières, 1884, re-made out of Smarties (Prudence Emma Staite, as reported in the Telegraph). ${ }^{12}$ The emphasis on the image also means, of course, that highly visual, spectacular art practices will be favoured over conceptual, process or research-based projects, ultimately skewing the kind of work that reaches the wider public sphere.

Another striking thing about newspaper coverage, and not just in the tabloids, is the great emphasis that is placed on the materials that artists use. Karla Black's nomination for the Turner Prize predictably provided an opportunity for this. The Daily Mail describes her work as 'folds of plastic sheeting hanging from the ceiling,' and reports that she is 'best known for a sculpture composed of mud, compost and top soil - with hairspray to keep it in place'. ${ }^{13}$ The Sun describes the same piece as a 'pile of dirt, sand and gravel, ${ }^{, 14}$ while the Guardian prefers to focus on her use of 'nail varnish, eyeshadow and moisturiser,' 'lipstick, bath bombs and bronzing powder. ${ }^{15}$ Fellow nominee George Shaw is also reported as using the 'Humbrol enamels of his modelpainting youth' in The Times, ${ }^{16}$ and 'the kind of enamel paint used for decorating model trains and aeroplanes' in the Guardian.

This focus on the artwork's raw materiality rather than its content, context or meaning picks up a more explicitly negative emphasis when given 
greater prominence in headlines or sub headings. Passing quickly over the Daily Mirror's 'Lippycasso' headline, ${ }^{17}$ the Daily Mail's incredulous subheading reads 'Suspended ball of plastic is favourite to win prize'. ${ }^{18}$ While the Sun is clearly aiming to create a dramatic juxtaposition of high and low with 'Dirt and gravel artist up for $£ 25 \mathrm{k}$ Turner Prize'. ${ }^{19}$ This artificially heightened opposition contains an implicit questioning of the artist's abilities and jurors' judgement: how could mere dirt and gravel ever possibly be worth $£ 25,000$ ?

All this emphasis on raw materiality could charitably be understood as reflecting journalistic uncertainty about contemporary art. For a non-specialist news reporter it would be safer to describe it in empirical, material terms rather than attempt the kind of interpretive reading that a dedicated arts correspondent would be more comfortable with. However, an entirely material description of an artwork inevitably misses the point of most contemporary work. No one would dispute that Shaw's works are painted in Humbrol model paint, whereas the significance of that choice expands the set of meanings surrounding his images, and it is these very connotations that are interesting. The reductive describing of artworks in terms of their materials harks back to a pre-twentieth century attitude that equates fine or expensive art materials with elevated values. Good pictures are only made from good quality paints. Noble people are sculpted in noble materials like marble or bronze. Does this traditional academic attitude really persist in today's journalistic culture? It is a hundred years now since the avant-garde showed that art can be collage, performance, found objects, or anything else at all.

On the other hand, it would be disingenuous to claim that today's artists are entirely naïve about the impact that their choice of materials has. George Shaw uses Humbrol enamels specifically in order to make his work more mundane, and bring in these connotations of adolescent obsessiveness. Indeed, Karla Black's whole practice is based on the relationships and frictions between the base materialism and cultural resonances of her materials. The mainstream media seems sadly unable to deal with the complexities of this discourse, but it does appear, inverted, in the frequent focus on unusual, low or 'inappropriate' materials.

Underlying these aspects of the artist as celebrated rule-breakers, makers of original images and users of unorthodox materials lays the traditional idea that they are 'representative of non-forced and truly expressive activity. ${ }^{20}$ Having the freedom to create outside of society's usual social structures allows artists to inhabit these archetypes. In fact it could be claimed that performing the role of a contemporary artist often actually requires it. The political story of Ai Weiwei's incarceration by the Chinese authorities only serves to reemphasise this notion of the importance of completely free self-expression. At the time of the study he had been missing from the public eye for forty-five days with no charges made against him. The coverage is mostly written in political terms, with Weiwei referred to as a 'dissident artist,' who 'always knew he could end up in prison'. ${ }^{21}$ Most of the discussion is around the campaign to have him released, and the inadequate response of British politicians. Well-known artists, including Anish Kapoor, Antony Gormley, David Hockney, Grayson Perry, Cornelia Parker, and Damien Hirst, used their celebrity power to draw media attention to the campaign. The stance of the political dissident aligns neatly with the idea that artists must be self-expressive at all costs, and furthermore, that this self-expression is something that takes place somehow beyond or above the normal structures of culture and society.

It seems evident that the most frequent types of narrative around contemporary art in the press continue to be based on the idea of the artist as a 
uniquely free and self-expressive individual. The archetype is evidently a tenacious one, one that Victor Burgin has shown has survived since at least the Romanticism of the eighteenth century. ${ }^{22}$ The figure of the artist as celebrity is reliant on the artist's unorthodox appearance or behaviour; unusual subject matter or the use of unusual materials is held as evidence of the way that artists are different from 'normal people;' and artists are frequently held up as totems of free expression in the form of social or political protest. In the accelerated commercial environment of the twenty-first century, this freedom of expression is often commodified and recouped in the form of novel images and quirky stories for the content-hungry media, a process in which the artist may be complicit by way of developing their image into a recognisable brand. In this way the artist can be simultaneously an outsider figure and a necessary cog in the machine.

The other main narrative paradigm that is found in this study is connected above all to art's commercial and financial value. The tremendous sums achieved at auction often make stories in themselves, such as a small item in the Daily Mirror of 12 May 2011. 'Artist Jeff Koons's sculpture of TV cartoon character Pink Panther hugging a bare-breasted blonde has fetched $£ 10.1$ million at auction' reports the brief story, noting that a previous work fetched $£ 15.6$ million. ${ }^{23}$ The low-culture forms of a TV cartoon character and a 'barebreasted blonde' are juxtaposed with the huge sum of money to create an instant story that needs no further elaboration. It is enough just to amaze or impress the reader, who might silently say 'wow' before turning the page. On the one hand this kind of item only reflects the buoyant market for contemporary art, but the subtext is surely that this is a ridiculous sum. The art industry is portrayed as an elaborate system for creating wealth or value out of thin air, a suspicious kind of magic.

Finally, on a larger scale, this financial magic takes place again in the form of culture-led 'regeneration,' where whole towns and cities can be blessed with the rejuvenating power of art. This has become an increasingly popular argument for arts funding in the last few decades, and apparent success stories like Gateshead, in the North East of England, and Peckham, in South London, mean that the concept is more widely understood. A short item in the Daily Mirror of 27 May 2011 reports on the opening of the Hepworth Gallery in Wakefield, with a small image of a Barbara Hepworth sculpture captioned simply 'sculpture'. The story notes that visiting galleries can be good for your health, and that the new gallery 'will generate needed tourist revenue and employ many young people who would otherwise be on the dole'. ${ }^{24}$ The value of contemporary art is much more easily understood and appreciated when stated in monetary terms like this. A much larger feature in the property section of the Daily Mail of 13 May 2011 profiles the rising fortunes of Margate and the new Turner Contemporary gallery, along with an obligatory photo of Tracey Emin. After reporting some rather negative critical comments on the architecture of the gallery, the journalist notes that 'the idea is that Turner Contemporary will do for Margate what the Tate has done for St Ives in Cornwall or, indeed, what the Guggenheim is doing for Bilbao in northern Spain'. ${ }^{25}$ The rest of the piece consists of positive quotes from local estate agents talking up the rising property values and Victorian character of the town, with no further mentions of art or the gallery. It is clear that the regeneration potential of having a major new art gallery in the town is well understood, and that this is one of the taken-for-granted powers of art today.

This study of the British daily press presents a typical slice of public opinion on contemporary art and the nature of the figure of the artist. As I have 
shown, the most common types of narrative are all based on the implicit assumption that the artist is somehow different to ordinary people, able to express her/himself 'spontaneously in the face of an environment asking him to conform'. ${ }^{26}$ This is a very longstanding archetype with roots that reach back beyond Romanticism to the Renaissance and the belief in unfettered expression and unmediated experience. The most frequent categories of news story I have found are all based on this archetype, no matter that it has been profoundly challenged and debunked by a hundred years of Modernism, postmodernism and sophisticated cultural critique.

My initial thesis is that the main narratives of news media coverage of contemporary art in fact echo in distorted form some of the major tropes and shibboleths of the contemporary art community. It is not a simple matter of a choice between tortured genius and con man. The media's preferred narrative paradigms are translations from one specialised discourse to another more generalized one. In understanding the mechanisms of these translations, we come to understand more about the two different communities of discourse. There is also a political reading of these translations that highlights the media's refusal to engage with art's radical critical content in favour of feigned shock or trivialisation.

The newer paradigm of the art world as the creator of financial value and economic regeneration is obviously influenced by the decades-long boom in auction prices that seems to survive recession, scandal and legal investigation. But it also surely reflects that fundamental urge of avant-garde art to give aesthetic value to the lost and forgotten detritus of industrial society. Newspaper collages, inverted urinals, scrap metal assemblages and all the familiar junk materials of twentieth-century art testify to the longstanding artistic appeal of this stance. As artists question the value of traditional forms and materials, they also promote the value of the neglected. In this way, a radical aesthetic transformation leads ultimately to a financial transformation, and it is this aspect of the process that the mainstream press picks up on when it portrays artists and galleries as economic drivers and creators of financial value.

This small study establishes some benchmark data and suggests interesting lines of inquiry. To understand whether there has truly been a transformation in public and media attitudes to art since the early 1990s it will be necessary to conduct similar studies on historic newspaper samples and compare them with today's media. Stereotypes, misunderstandings and simple factual inaccuracies build up over the long term to create negative perceptions, and conservative voices will always attempt to negate the progressive force of an avant-garde art that threatens their cultural and economic interests. Financial and cultural investment in historic artworks is threatened by the rising value of more radical, conceptual or dematerialised art forms, especially when validated by large museums and institutions. Everyone involved with contemporary art should be concerned with how it is portrayed, received and understood. The best defence against a hostile media will surely be to understand how and why some narratives are promoted over others, in order that a more nuanced paradigm might prevail.

Norwich University of the Arts 


\section{Notes}

1 British Council, Visual Arts (2010) <http://visualarts.britishcouncil.org $>$ [accessed 20 December 2010].

2 Neil Mulholland, 'Cultural Devolution: Art in Britain in the Late Twentieth Century' (Aldershot: Ashgate, 2003), pp. 5-30.

Mark Wilsher, 'Lost \& Found', Art Monthly, 378 (2014), p. 5-7.

Catherine Happer and Greg Philo, 'The Role of the Media in the Construction of Public Belief and Social Change', Journal of Social and Political Psychology, 1.1 (2013), 321-336 (p. 321).

Tate Report 2013/14 (London: Tate, 2014), p. 92.

Philip Hayward, Picture This (Luton: University of Luton, 1999), p. 11.

Janet Wolff, The Social Production of Art (London: Macmillan, 1981), p. 12.

Donald Kuspit, The Cult of the Avant-Garde Artist (Cambridge: Cambridge University Press, 1993), p. 20.

Kate Jackson, 'Work of Parts', Sun, 6 May 2011, p. 37.

'An Art Attack Victim', Daily Mirror, 17 May 2011, p. 31.

Patrick Kingsley, 'Rubik-Cubism', Guardian, 9 May 2011, p. 3.

'A Gallery with a Difference: Art Made out of Unusual Materials', Daily Telegraph

(website) <http://www.telegraph.co.uk/news/picturegalleries/howaboutthat/

4374632/A-gallery-with-a-difference-art-made-out-of-unusual-materials.html? image $=5>$ [accessed 23 January 2015].

Emily Andrews, 'It Could Only Be Turner', Daily Mail, 5 May 2011, p. 30.

Neil Millard, 'It's Mudern Art', Sun, 5 May 2011, p. 12.

Charlotte Higgins and Adrian Searle, 'Turner 2011: Paint, But Not As You Know It', Guardian, 5 May 2011, pp. 2-3.

Rachel Campbell-Johnston, 'Turner Prize Finalists Put on Variety Show', The Times, 5 May 2011, p. 21.

Martin Newman, 'Lippycasso', Daily Mirror, 5 May 2011, p. 21.

Andrews, 'It Could Only Be Turner', p. 30.

Millard, 'It's Mudern Art', p. 12.

Wolff, The Social Production of Art, p. 18.

Soraya Kishtwari, 'Downing Street is put in the Picture over Call on China to Free Weiwei', The Times, 19 May 2011, p. 6.

Victor Burgin, The End of Art Theory: Criticism \& Postmodernity (London: Macmillan, 1986), p. 148

'In the Pink ... at Cool £10M', Daily Mirror, 12 May 2011, p. 33.

Paul Routledge, 'Twitching to see Museum's Heron', Daily Mirror, 27 May 2011, p. 37.

Mark Palmer, 'Marvel at Margate', Daily Mail, 13 May 2011, p. 66.

Kuspit, The Cult of the Avant-Garde Artist, p. 7.

\section{Works Cited}

'A Gallery with a Difference: Art Made out of Unusual Materials', Daily Telegraph (website) <http://www.telegraph.co.uk/news/picture galleries/howaboutthat/4374632/A-gallery-with-a-difference-art-madeout-of-unusual-materials.html?image $=5>$ [accessed 23 January 2015]

'An Art Attack Victim', Daily Mirror, 17 May 2011, p. 31

Andrews, Emily, 'It Could Only Be Turner', Daily Mail, 5 May 2011, p. 30

British Council, Visual Arts (2010) < http://visualarts.britishcouncil.org> [accessed 20 December 2010]

Burgin, Victor, 'The End of Art Theory: Criticism \& Postmodernity' (London: Macmillan, 1986)

Campbell-Johnston, Rachel, 'Turner Prize Finalists Put on Variety Show', The Times, 5 May 2011, p. 21

Happer, Catherine and Philo, Greg, 'The Role of the Media in the Construction of Public Belief and Social Change', Journal of Social and Political Psychology, 1:1 (2013), 321-336 
Hayward, Philip, Picture This (Luton: University of Luton, 1999)

Higgins, Charlotte and Searle, Adrian, 'Turner 2011: Paint, But Not As You Know It', Guardian, 5 May 2011, pp. 2-3

'In the Pink ... at Cool £10M', Daily Mirror, 12 May 2011, p. 33

Jackson, Kate, 'Work of Parts', Sun, 6 May 2011, p. 37

Kingsley, Patrick, 'Rubik-Cubism', Guardian, 9 May 2011, p. 3

Kishtwari, Soraya, 'Downing Street is put in the Picture over Call on China to Free Ai Weiwei', The Times, 19 May 2011, p. 6

Kuspitt, Donald, 'The Cult of the Avant-Garde Artist' (Cambridge: Cambridge University Press, 1993)

Millard, Neil, 'It's Mudern Art', Sun, 5 May 2011, p. 12

Mulholland, Neil, 'Cultural Devolution: Art in Britain in the Late Twentieth Century' (Aldershot: Ashgate, 2003)

Newman, Martin, 'Lippycasso', Daily Mirror, 5 May 2011, p. 21

Office of National Statistics (2014) 'Overview of UK Population' $<$ http://www.ons.gov.uk/ons/rel/pop-estimate/population-estimatesfor-uk--england-and-wales--scotland-and-northern-ireland/mid2014/sty---overview-of-the-uk-population.html> [accessed 23 November 2015].

Palmer, Mark, 'Marvel at Margate', Daily Mail, 13 May 2011, p. 66

Routledge, Paul, 'Twitching to see Museum's Heron', Daily Mirror, 27 May 2011, p. 37

Tate Report 2013/14 (London: Tate, 2014)

Wilsher, Mark, 'Lost \& Found', Art Monthly, 378 (2014), 5-7

Wolff, Janet, 'The Social Production of Art' (London: Macmillan, 1981) 